https://helda.helsinki.fi

\title{
Faith and Rhetoric in Giles of Rome
}

\section{Faucher, Nicolas Pierre}

2019

Faucher, N P 2019 , ' Faith and Rhetoric in Giles of Rome ' , Vivarium , vol. 57 , no. 1-2 , pp.

1-21 . https://doi.org/10.1163/15685349-12341368

http://hdl.handle.net/10138/324003

https://doi.org/10.1163/15685349-12341368

acceptedVersion

Downloaded from Helda, University of Helsinki institutional repository.

This is an electronic reprint of the original article.

This reprint may differ from the original in pagination and typographic detail.

Please cite the original version. 


\title{
Faith and Rhetoric in Giles of Rome
}

\author{
Nicolas Faucher
}

nicolas.faucher@live.fr

Academy of Finland's Centre of Excellence in Reason and Religious Recogntion, Helsinki

\begin{abstract}
:
Giles of Rome's position on the nature of faith in the reportatio of his questions on book III of the Sentences (q. 38, d. 23) is distinctively founded on a comparison between faith and rhetoric. For Giles, just as the rhetorician makes her audience members believe by appealing to their emotions and thus to the power of their will to make their intellect assent to what the rhetorician asserts, faith produces belief based on the believer's love for God, which motivates the will to cause the intellect to believe in Him. This paper argues that this is made possible by Giles' move away, in his commentary on Aristotle's Rhetoric, from Aquinas' position on the nature of the assent produced by rhetorical discourse. While Aquinas thought rhetoric could only produce weak intellectual assent, Giles affirms that, based on the will's control over the intellect, it can produce strong assent, such as that dogmatically required of theological faith. According to Giles, the affective bias produced by rhetoric serves as a model for conceiving the psychological process that leads the faithful to believe. The new function that Giles gives to rhetoric underlines of the evolution of thirteenth-century views on faith, as shown through a comparison of Giles' view with two other doctrines of faith that use examples similar to the one Giles employs, namely those of Philip the Chancellor and Peter John Olivi. Both defend the same kind of doxastic voluntarism but to very different ends. For the former, faith founded on affective bias is a typical example of non-virtuous faith, while for the latter, just as for Giles, it is the very model of virtuous faith.
\end{abstract}

\section{Keywords:}

Faith - Rhetoric - Giles of Rome - Thomas Aquinas - Philip the Chancellor - Peter John Olivi

Giles of Rome $(\dagger 1316)$ is well known as one of the most influential thinkers of the late thirteenth and early fourteenth centuries. Among his many works, he composed questions on the Sentences of Peter Lombard ${ }^{1}$ and the most important medieval commentary on

\footnotetext{
${ }^{1}$ See C. Luna, "La Reportatio della lettura di Egidio Romano sul libro III delle Sentenze e il problema dell'autenticità dell'Ordinatio," Documenti e studi sulla tradizione filosofica medievale 1 (1990), 113-225,
} 
Aristotle's Rhetoric, ${ }^{2}$ influencing all subsequent commentaries. ${ }^{3}$ It is thus not surprising that rhetoric plays a particularly important role in his other works. Like many other medieval theologians, Giles devotes distinction 23 of book III of his questions on the Sentences to the nature of the act of faith. What makes his way of dealing with the question distinctive is that he elucidates it by means of a comparison between the assent that is characteristic of faith and that which is produced by rhetorical persuasion. For medieval authors, an act of faith is an act of intellectually assenting to the truth of something, usually a proposition, in an absolutely, subjectively certain and doubtless manner. This assent and its certainty do not depend on the available evidence in favor of the truth of what is believed. Rather, they depend on the will, which commands the intellect to assent. ${ }^{4}$ Similarly, a rhetorical discourse would produce in its audience emotions leading the will to command assent to the truth of a certain proposition.

Throughout the thirteenth century theories of religious faith underwent a process of naturalization in the sense that the place supernatural processes occupied in the explanation of the production of the habitus and act of faith was considerably reduced, ${ }^{5}$ until it became marginal for John Duns Scotus (ca. 1266-1308). ${ }^{6}$

For Scotus, the supernatural infused habitus of faith would still be necessary for any act of faith to be truly virtuous and meritorious, but the natural causal impulse of the will was the main source of the certainty of faithful assent and the acquisition of the natural habitus of faith. A natural act of faith, proceeding from this habitus, would not be seen as an imperfect alternative to a supernatural one. Rather, a virtuous act of faith had to proceed from both the natural and supernatural habitus. This means that the certainty of one's virtuous acts of faith comes mainly from one's own will, since Scotus uses an

and 2 (1991), 75-146. The only surviving version of the third book of Giles' Sentences questions is a reportatio, which is not as trustworthy as an ordinatio and may explain any doctrinal discrepancy between this reportatio and Giles' commentary on Aristotle's Rhetoric; see, e.g., n. 21.

2 See C. Marmo, "L'utilizzazione delle traduzioni latine della Retorica nel commento di Egidio Romano (1272-1273)," in La Rhétorique d'Aristote. Tradition et commentaires de l'antiquité au XVII siècle, ed. G. Dahan and I. Rosier-Catach (Paris, 1998), 111-134; U. Staico, "Retorica e politica in Egidio Romano," Documenti e studi sulla tradizione filosofica medievale 3 (1992), 1-75.

${ }^{3}$ R. Lambertini, "Giles of Rome," in The Stanford Encyclopedia of Philosophy, ed. E.N. Zalta (winter 2014 edition).

${ }^{4}$ N. Faucher, Les garanties de la foi chez les penseurs franciscains du XIII ème siècle et du début du XIVème siècle (PhD dissertation, Paris-Bari, EPHE-Università di Bari, 2015.

${ }^{5}$ Faucher, Les garanties de la foi.

${ }^{6}$ N. Faucher, "Prêter foi avec parcimonie. Le traitement scotiste de la foi acquise et de la foi infuse," Conviction, croyance, foi: pistis et fides de l'Antiquité tardive au Moyen Âge, ed. C. Grellard, P. Hoffmann, and L. Lavaud (Turnhout, forthcoming). 
argument of economy according to which if humans can do something by themselves, we ought not posit the existence of any divine help for the accomplishment of this thing. Common experience shows us that we can take some propositions to be absolutely certain even though we have no evident proof for them and have to rely on the testimony of fallible humans to know and believe them. Therefore, no supernatural help is needed to explain the certainty of our religious beliefs.

One of the key features of such naturalistic doctrines, as exemplified by Scotus', is the use of comparisons between religious faith and ordinary voluntary firm belief in order to draw up for both a common conceptual framework. It seems that beliefs produced by rhetorical discourse would constitute a good example of voluntary firm belief. Indeed, in Giles' Rhetoric commentary I discern a conceptual shift from Thomas Aquinas' (12251274) conception of rhetoric to one that allows for identifying beliefs produced by rhetorical discourse as voluntary belief akin to faith. This shift is a remarkable example of the progressive process of naturalization of the theories of faith in the thirteenth century. I will not make a historical argument regarding the influence Giles exerted on his successors in this process, but I will nonetheless argue that Giles' conceptual shift from Aquinas can be seen as a particularly explicit instance of this process.

In this paper I first offer an explanation for and analysis of Giles' conception of faith and the exact nature of the analogy he proposes with rhetoric. I then endeavor to show that this is made possible by a precise conceptual shift from Aquinas' views on rhetoric. Finally, I compare Giles' view with those of Philip the Chancellor (1160s-1236) and Peter John Olivi (ca. 1248-1298) and suggest that the difference between the three is remarkably illustrative of the evolution of thirteenth-century doctrines of faith.

\section{The Role of Rhetoric in Giles' Model of Faith}

In distinction 23 of his questions on book III of the Sentences, Giles asks, "Is the act of faith thinking in assent?"7 This can be rephrased as follows: can the act of faith be defined as an act of thinking about a certain proposition while assenting to it? It alludes to Augustine's famous definition of believing: ipsum credere nihil aliud est quam cum

\footnotetext{
${ }^{7}$ Aegidius Romanus, Reportatio in III Sententiarum, q. 38, d. 23 (Opera omnia 3/2. Reportatio lecturae super libros I-IV Sententiarum; Reportatio Monacensis; Excerpta Godefridi de Fontibus, ed. C. Luna, Florence, 2003, 439): "Quaeritur utrum actus fidei sit in assensu cogitare."
} 
assensione cogitare. ${ }^{8}$ Appealing to this particular Augustinian passage is common for medieval authors, often the starting point for reflecting on what exactly believing is and on what specific interplay of will and intellect is involved in it. The way in which Giles proceeds, by contrast, is highly unusual: he compares faith "as it pertains to the rhetor" and "faith in theology," indicating that they are similar. ${ }^{9}$ Giles arrives at his answer to the original question by explaining precisely what this similarity is.

Before he arrives at this comparison, however, and in order to show that the rhetor can indeed produce faith and to explain how he does it, Giles makes another comparison, between faith as it pertains to the rhetor and faith as it pertains to the dialectician: "Both determine the intellect through non-necessary means, though in different ways, because sometimes the intellect is determined according to its proper manner, i.e., that of reason, [but] sometimes, [it is determined] according to the command of the will." 10

This brief passage tells us three things: first, the intellectual assent dealt with here is not science or knowledge produced by necessary means or arguments that, if correctly understood, cause the intellect to assent firmly and without doubt or hesitation, like simple mathematical or logical demonstrations. By contrast, the dialectician only uses probable arguments and produces only opinion. ${ }^{11}$ Such arguments merely make the intellect lean in a certain direction. The attitude they produce, opinion, is always accompanied by the fear that what is opined might be false. Indeed, an opinion can always be replaced by another opinion, should circumstances change or other arguments be found.

Second, as a corollary to the first point, we can see that the term fides is used here in a very broad sense that includes at least religious faith (or faith "in theology"), opinion, and whatever belief is produced by rhetoric. This is not unusual, ${ }^{12}$ but should be taken as a

\footnotetext{
${ }^{8}$ Augustinus, De Praedestinatione sanctorum II, c. 5 (PL 44, col. 963).

${ }^{9}$ Aegidius Romanus, Reportatio III, q. 38, d. 23 (ed. Luna, 439): "Dicendum quod fides, secundum quod pertinet ad rethorem, similitudinem habet cum fide in theologia."

${ }^{10}$ Aegidius Romanus, Reportatio III, q. 38, d. 23 (ed. Luna, 439): “Quod patet sic: aliter fides pertinet ad rethorem, aliter ad dyalecticum. Primo, in hoc est convenientia, quod uterque determinat intellectum per medium non necessarium, licet diversimode, quia intellectus quandoque determinatur secundum modum proprium, scilicet rationis, quandoque secundum imperium voluntatis."

${ }^{11}$ Aegidius Romanus, Reportatio III, q. 38, d. 23 (ed. Luna, 440): "Dyalecticus vero determinat intellectum ad assentiendum secundum modum proprium intellectus, scilicet per rationem probabilem. Et ideo ipsius est probare et adgenerare opinionem."

12 The term fides is regularly used in medieval texts to mean either belief in the broadest sense, as is the case here, or in a more specialized sense popularized in particular by Hugh of Saint-Victor: fides is defined as opposed to opinio and scientia. One who opines the truth of a certain proposition believes it hesitantly, while one who has faith or science as regards this truth believes it firmly. Furthermore, opinion and faith have obscure objects, which are not fully understood, while science understands its objects clearly. Such
} 
sign that the term fides is used by Giles to designate a continuum of belief with diverse characteristics rather than a specific kind of belief. As will be seen shortly, credulitas seems to be the more proper term to speak of the kind of belief dealt with here.

Third, Giles clearly assumes a form of doxastic voluntarism: he admits that, in one way or another, the will can cause the intellect to adopt a certain belief. ${ }^{13}$ Through a concrete example, taken from daily life, Giles shows why we need to assume this. Suppose a certain dialectical argument is used to persuade someone of something good regarding a friend of his, e.g., that he is an honest man. If this were the only way the intellect could be persuaded to believe something, then such an argument could be used with the same efficiency to persuade the same person that an enemy of his is an honest man. But it so happens that this is not the case: on the basis of the same argument, mutatis mutandis, this person accepts that his friend is honest but not that his enemy is. It must be assumed then that the argument is not the only thing that can influence the intellect and that the will is what causes this otherwise unaccountable disparity. ${ }^{14}$ Indeed, the will is the faculty of volition as well as emotion and affection for medieval authors. Loving one's friend is an act of the will. If this love is the cause of the intellect's accepting or refusing the truth of a certain proposition, then it is ultimately the will that determines the intellect in this particular case.

For Giles, this determination of the intellect by the will is at the heart of rhetorical persuasion. Indeed, rhetoric, as opposed to dialectic, deals with moral matters and with

clarity of understanding, sometimes called evidentia, is what grounds the firmness of scientific assent. By contrast, since faith does not have such clarity, its firmness must be grounded in something else, such as God's grace, human authority, the power of the will, or any combination of these. See Faucher, Les garanties de la foi; idem, "Prêter foi avec parcimonie"; idem and M. Roques, "L'épistémologie de la croyance d'après Guillaume d'Ockham," Freiburger Zeitschrift für Philosophie und Theologie 62 (2015), 219-239; C. Grellard, "Argumentation topique et production de la croyance chez Jean de Salisbury," in Le syllogisme topique de l'antiquité à l'âge classique, ed. J. Biard and F. Mariani Zini (Turnhout, 2010), 227247; idem, De la certitude volontaire (Paris, 2014).

${ }^{13}$ Doxastic voluntarism is broadly understood as the doctrine according to which humans are capable to voluntarily choose what they believe. There are variations to this doctrine, ranging for instance from consensual indirect voluntarism (we can choose to take steps to produce in ourselves a belief, for instance, studying a topic to acquire a belief about it) to the controversial direct voluntarism (our decision to believe causes our belief without any intermediary). See, e.g., R. Audi, "Doxastic Voluntarism and the Ethics of Belief," in Knowledge, Truth and Duty, ed. M. Steup (Oxford, 2001, 93-111); D. Frederick, "Doxastic Voluntarism: A Sceptical Defence," International Journal for the Study of Skepticism 3 (2013), 24-44.

${ }^{14}$ Aegidius Romanus, Reportatio III, q. 38, d. 23 (ed. Luna, 439-440): "Et quod differunt isti modi, hoc experimur in nobis ex hoc quod aliquis aliter se habet ad dilectum et ad odibilitatem. Si enim aliquod bonum per rationem persuaderetur de amico, et eadem ratione de inimico. Si tamen intellectus solus determinaretur ad assentiendum $<$ de $>$ inimico sicut de amico, sed hoc est per imperium voluntatis quod assentit rationi de amico, non $<$ de $>$ inimico." 
passions. The work of the dialectician is to prove and generate opinion; but the work of the rhetor is to arouse a passion, an affection in the will so that it may command the intellect to assent to a certain proposition that is in line with this passion. The assent produced by such a persuasion is called credulitas. ${ }^{15}$

The rhetor deals with moral matters in order to persuade, because "such as one is, so does the end appear to her." 16 Moral matters have to do with the proper objects of the will: the bad and the good, what is to be eschewed and what is to be sought as one's end. In point of fact, if an intellectual act of belief did not appear as good or bad in some way, the will would simply be indifferent to it and would not be able to cause the intellect to elicit it or refuse it. We can thus understand that any persuasive argument, inasmuch as it is geared to produce voluntary belief, is always a practical argument, for it aims at showing that one ought to believe or not to believe because believing is good or bad, rather than rational or irrational because of a high or low degree of probability. If a rhetor manages to create in an audience the desire for a certain type of food, they will want to believe that this food is good for them. Otherwise they might have to renounce it and they do not want that.

Now that we understand Giles' view on rhetorical persuasion, let us see what it has to do with religious faith. This is quite straightforward. ${ }^{17}$ In Giles' mind, "the opposite of the faith has more efficacious arguments [in its favor] than the objects of the faith." Therefore, left to itself, an intellect would never adhere to the truths of faith: reasoning

15 Aegidius Romanus, Reportatio III, q. 38, d. 23 (ed. Luna, 440): "Et ideo dyalecticus descendit in scientiam arguendi medium necessarium ut probabile, sed non descendit in materiam moralem nec determinat de istis passionibus: gaudium, tristitia etc. Sed rethor determinat intellectum per imperium voluntatis ad assentiendum [asserendo], et ideo ipsius non est probare, sed persuadere iudici et adgenerare credulitatem." The term credulitas is to be understood here not as a disposition to believe easily but as the particular kind of belief that is produced by persuasion (as is clarified in Giles' commentary to Aristotle's Rhetoric), and thus by the command of the will: Aegidius Romanus, Expositio super libros Rhetoricorum Aristotilis (Venice, 1515, f. 1rb): “[P]er rationes probabiles generatur opinio. Per persuasivas fides aggeneratur, sive credulitas. Per demonstrativas vero efficitur scientia."

16 Aegidius Romanus, Reportatio III, q. 38, d. 23 (ed. Luna, 440): "Et ideo descendit in materiam moralem, ut melius persuadeat, quia qualis est unusquisque, talis finis videtur sibi (malitia est corruptiva principii). Et ideo determinat intellectum non per rationem propriam intellectus, sed per modum voluntatis quo movet iudicem, ut ex hiis que sunt in voluntate, esset $<$ adgenerare $>$ errorem in rationem iudicis. Et ideo rethor non politicus bonus, sicut dyalecticus $<$ non $>$ bonus geometra."

${ }^{17}$ Aegidius Romanus, Reportatio III, q. 38, d. 23 (ed. Luna, 440): "Fides autem determinat intellectum ad assentiendum per modum voluntatis, non secundum rationem propriam intellectus, immo contrarium fidei habet rationes efficaciores quam ea que sunt fidei. Ideo oportet captivare intellectum. Unde Apostolus: captivantem intellectum in obsequium Christi etc. Sed quod consentit intellectus, hoc est ex imperio voluntatis, quia tamen ostenditur ei ex aliquo auditu vel ratione quia hoc est dictum divinum etc. Et ideo dicit Augustinus: aliqua possum facere nolens, credere nonnisi volens. Et ex hoc patet quod actus fidei est cum assensu cogitare." 
would lead it to reject them. ${ }^{18}$ Thus, the intellect must be "captured" or "captivated." And, just as in rhetorical persuasion, it is by the command of the will that the intellect can be made to consent in this way. Giles can finally answer his own question: the act of faith is indeed "thinking in assent." It is thinking of the objects of faith and consenting to the command of the will, which pushes the intellect to firmly assent to them, i.e., to deem them to be true in a stable, not hesitant manner.

Giles gives us some further insight into how this works and how it is comparable to rhetorical persuasion:

[I]t must be noted that there are three acts of faith, just as the rhetor persuades a judge in three ways: in one way, on the part of the speaker, by saying that he is such that one must believe him and that he is knowledgeable; in another way, on the part of the audience, by engendering a passion in the mind by which it is inclined to it, just as, if [the rhetor] wanted to move [the audience to] war, he would engender in them the passion of anger; in the third way, on the part of the ornament of the discourse. Similarly, there are three acts of faith: one on the part of the believer, inasmuch as it proceeds from his emotion (affectus), and this is credere in Deum; in another way, on the part of the speaker, and this is credere Deum; in a third [way], on the part of things, and this is credere Deo. ${ }^{19}$

The three credere, which I have left in Latin on purpose, refer to the triple definition of the term credere that is accepted by medieval theologians. ${ }^{20}$ It is usually understood thus:

18 One might wonder what exactly Giles means when he says that the arguments against faith are more efficacious. Is it the case for any man who would reason, in such a way that no one could reasonably believe? Or does this depend on the full examination of every available argument, which supposes a vast culture? Or is it perhaps a judgment regarding the situation of the average man using mainly his common sense to make up his mind on the objects of faith? Regardless of the answer, which Giles does not give, we can assume as a situation of reference that of a man whose mere intellectual judgment would not and could not lead him to believe.

${ }^{19}$ Aegidius Romanus, Reportatio III, q. 38, d. 23 (ed. Luna, 441): "Et notandum quod tres sunt actus fidei, sicut rethor triplici via persuadet iudici: uno modo, ex parte dicentis, dicendo se esse talem cui credendum et esse scientem; alio modo, ex parte audientis, adgenerando passionem in animo per quam inclinetur ad ipsum, ut si vellet movere bellum, adgenerat in eo passionem ire; tertia via, ex parte sermonum ornatorum. Sic triplex actus fidei: unus ex parte credentis, secundum quod procedit ex affectu suo, et hoc est credere in Deum; alio modo, ex parte dicentis, et hoc est credere Deum; tertio, ex parte rerum, et hoc est credere Deo."

20 See T. Camelot, “Credere Deo, credere Deum, credere in Deum. Pour l'histoire d'une formule traditionnelle," Revue des Sciences philosophiques et théologiques 30 (1941-1942), 149-155. Medieval authors generally take credere Deo to mean believing what God says and credere Deum to mean believing 
credere Deo is the most usual in terms of grammatical construction and simply means believing God, believing what God says. This is why it has to do with things: it is believing the things that God has said. There does not seem to be any specific link with the ornament of the discourse mentioned before. ${ }^{21}$ Credere Deum is believing in God in the sense of believing that He exists and He is God, with all the attributes given to Him in the Creed. Thus, it makes sense that it be a parte dicentis and linked to the persuasion derived from the personal qualities of the rhetor: just as one ought to believe the rhetor because he is truthful and knowledgeable and his reputation lends credit to his words, God's word is to be believed because He is truth itself, He would never support false belief, He knows all, and other likely reasons. Credere in Deum can also be translated as believing in God, but in the sense that one might believe in one's leader, with the love and trust it implies. Furthermore, it is literally believing towards God, in the sense that faithful belief is part of what leads one on the path towards God and eternal life. If we assume that a parte audientis is the counterpart of a parte credentis, we can also assume that the affection towards God implied by credere in Deum is compared to the passion produced by rhetorical discourse inasmuch as both constitute an affective drive to believe.

This comparison is most telling: as regards rhetoric, the a parte dicentis way and the a parte audientis way seem to be sharply distinct. The former has to do with the speaker

that God exists, usually by faith and according to the Creed, which entails believing things that cannot be rationally proven. On the meaning of these expressions, see, e.g., a number of passages in Bonaventura (Commentaria in Quatuor Libros Sententiarum Magistri Petri Lombardi III, d. 23, dub. 3, resp., in Opera theologica selecta III, Quaracchi-Florence, 1941, 494), Thomas Aquinas (Scriptum super Sententiis III, d. 23, q. 2, a. 2, qc. 2, arg. 3, co., et ad 2; Quaestiones disputatate de veritate, q. 14, a. 7, ad 7, Opera Omnia 22, vol. 2, ed. Leonina, Rome, 1972, 458; Summa theologiae II $^{\mathrm{a}}-\mathrm{II}^{\mathrm{ae}}$, q. 2, a. 2, co., Opera Omnia 8, ed. Leonina, Rome, 1895, 27), and Petrus Iohannis Olivi (Quaestiones de incarnatione et redemptione, quaestiones de virtutibus, q. VIII, resp. II, 3, ed. A. Emmen et E. Stadter, Grottaferrata, 1981, 323).

${ }^{21}$ Another reading of this passage is possible, if we refer to Giles' treatment of these three aspects of persuasion in his Rhetoric commentary. There, commenting on Aristole's Rhetoric I, c. 2, he reprises this tripartite distinction (which is already present in Aristotle, Rhetoric I, c. 2, 1356a): Aegidius Romanus, Expositio super libros Rhetoricorum Aristotilis (Venice, 1515, f. 2va): "Fides autem, quam assignare intendit rhetor, tripliciter habet fieri: videlicet ex parte auditoris, et ex parte dicentis, et rei." There is no mention of the ornament of the discourse and, when it comes to what a parte rei means, Giles says (f. 2va): "Tertia via ad generandum fidem sumitur ex parte rei, ut si quis enthimemata et persuasiones facit, per quae ei fides adhibeatur." In other terms, when one considers persuasion a parte rei, it is considered from the point of view neither of the speaker nor of the audience, but of the arguments made by the speaker. If we accept that this is the third aspect of ordinary rhetorical persuasion, then the link becomes clear: credere Deo refers neither to the believer and her motive nor to the speaker, but to what God says, just as persuasion a parte rei refers to the content of the rhetorical discourse. It makes sense that, though the human speaker makes arguments, God does not, since what is a parte dicentis (God's truthfulness) and a parte audientis (the emotions the hearer has towards the speaker) is enough to produce assent. It may be that the reportatio mentions the ornament of the discourse rather than the a parte rei side of persuasion because of a mistake made by the note taker and does not reflect Giles' view. 
while the latter works by causing a passion that depends on the content of the persuasion. It is tailored to a specific effect, with a specific object. By contrast, as regards faith, the $a$ parte dicentis act and the a parte credentis act both concern the speaker, namely God. It is out of love for God that one believes what He says, independently of its content. This explains what Giles said earlier: "It is by the command of the will that the intellect consents, because $[\ldots]$ it is shown to it by some audition or argument that this [object of faith] is something God has said, etc."22 Faithful belief is always belief in something because God, taken as a rhetor, has said it and $\mathrm{He}$ is to be believed out of love $\mathrm{e}^{23}$.

From the examination of Giles' text, we can conclude that, according to him, believing out of faith is just like believing because of a rhetorical persuasion, except that the passion involved is always love and it has the rhetor himself, namely God, as its object. By contrast, rhetorical persuasion seems to rely on a passion that depends and whose object depends on what specific proposition the object of persuasion is.

It is well known that Giles of Rome, who was probably a pupil of Aquinas, frequently developed his opinions with those of Aquinas in mind, whether he accepted or rejected them. I will now argue that Giles' view of faith, which is different though not explicitly opposed to Aquinas', is made possible by a specific disagreement with Aquinas on the strength of the assent induced by rhetoric.

\section{Giles' Disagreement with Aquinas on the Strength of Rhetorical Assent}

In the De veritate, Aquinas defends the following view on faith. Faith is a "simple light" that lends some of its perfection to the intellect inasmuch as it gives it firmness of adhesion. But, since it is not "perfectly participated," it cannot give it the perfect clarity

\footnotetext{
${ }^{22}$ Aegidius Romanus, Reportatio III, q. 38, d. 23 (ed. Luna, 440): “[...] quod consentit intellectus, hoc est ex imperio voluntatis, quia tamen ostenditur ei ex aliquo auditu vel ratione quia hoc est dictum divinum etc."

${ }^{23}$ Giles also mentions another position, of which he does not say whether he approves it or not: our will can cause our intellect to believe only when it has been persuaded to do it. In order to do that, it must be shown that catholic faith is better than other faiths or admirable. As is clear, it is still not a matter of showing that it is reasonable or not unreasonable to believe, which is the role of apologetics, but rather that faithful belief is good and thus should be commanded. According to such a position, faithful belief is even closer to belief produced by rhetoric given that the singular role of God does not differentiate them as it does in what appears to be Giles' own view.

Aegidius Romanus, Reportatio III, q. 38, d. 23 (ed. Luna, 440-441): "Alii dicunt quod nostra voluntas determinata ad assentiendum fidei non est, nisi saltem in generali $<$ ratio $>$ prius persuadeat voluntati. Unde Augustinus dicit numquam se credidisse fidem nostram nisi quia ratio sibi persuaderet prius quod esset melior aliis fidebus et mirabilis secundum conversationem inter eos qui fidem habent, et sic de aliis."
} 
of vision. ${ }^{24}$ This light, which causes the assent of faith and gives it firmness but not evidence, is identified with the first truth: God. ${ }^{25}$ In his questions on the Sentences Aquinas gives more detail: it is the will that commands the intellect to firmly adhere, but "the reason that inclines the will is the first truth itself - or God, Who is believed - which has more firmness than the light of the human intellect." ${ }^{26}$ A bit later, Aquinas explains that faith deals with objects that are above the nature of our reason; thus, to posit a proper act of faith, "we need a habitus that is not acquired." In other words, to have faith, as a belief whose truth is attested by God, we need a habitus given by God. ${ }^{27}$ Aquinas defends a similar view in the Summa theologiae. ${ }^{28}$

As we can see, Aquinas does not accept that there can be a proper act of faith without God's help. Nonetheless, he seems to accept the idea that some of our ordinary beliefs naturally proceed from affective processes: there can be firm, voluntary belief without divine help. ${ }^{29}$ But without a supernatural gift, such a belief cannot be said to rely on God

${ }^{24}$ Thomas Aquinas, Quaestiones disputatate de veritate, q. 14, a. 1, ad 5 (ed. Leonina, 438): “Ad quintum dicendum, quod fides habet aliquid perfectionis, et aliquid imperfectionis. Perfectionis quidem est ipsa firmitas, quae pertinet ad assensum; sed imperfectionis est carentia visionis, ex qua remanet adhuc motus cogitationis in mente credentis. Ex lumine igitur simplici, quod est fides, causatur id quod perfectionis est, scilicet assentire; sed in quantum illud lumen non perfecte participatur, non totaliter tollitur imperfectio intellectus: et sic motus cogitationis in ipso remanet inquietus."

${ }^{25}$ Thomas Aquinas, Quaestiones disputatae de veritate, q. 14, a. 1, ad 7 (ed. Leonina, 438): “Ad septimum dicendum, quod certitudo duo potest importare: scilicet firmitatem adhaesionis; et quantum ad hoc fides est certior etiam omni intellectu et scientia, quia prima veritas, quae causat fidei assensum, est fortior causa quam lumen rationis, quae causat assensum intellectus vel scientiae. Importat etiam evidentiam eius cui assentitur; et sic fides non habet certitudinem, sed scientia et intellectus: et exinde est quod intellectus cogitationem non habet."

26 Thomas Aquinas, Scriptum III, d. 23, q. 2, a. 2, qc. 3, co.: "In scientia vero conclusionum causatur determinatio ex hoc quod conclusio secundum actum rationis in principia per se visa resolvitur: in fide vero ex hoc quod voluntas intellectui imperat. Sed quia voluntas hoc modo non determinat intellectum ut faciat inspici quae creduntur, sicut inspiciuntur principia per se nota, vel quae in ipsa resolvuntur; sed hoc modo ut intellectus firmiter adhaereat; ideo certitudo quae est in scientia et intellectu, est ex ipsa evidentia eorum quae certa esse dicuntur; certitudo autem fidei est ex firma adhaesione ad id quod creditur. In his ergo quae per fidem credimus, ratio voluntatem inclinans, ut dictum est, est ipsa veritas prima, sive Deus, cui creditur, quae habet majorem firmitatem quam lumen intellectus humani, in quo conspiciuntur principia, vel ratio humana, secundum quam conclusiones in principia resolvuntur; et ideo fides habet majorem certitudinem quantum ad firmitatem adhaesionis, quam sit certitudo scientiae vel intellectus: quamvis in scientia et intellectu sit major evidentia eorum quibus assentitur."

27 Thomas Aquinas, Scriptum III, d. 23, q. 3, a. 2, co. "Nulla autem potentia secundum suam naturam determinatur ad illa quae sunt supra naturam rationis nostrae, quorum est fides; et ideo ad hunc actum indigemus habitu, qui non est acquisitus: qui quidem in duobus nos adjuvat: in hoc scilicet quod intellectum facit facilem ad credendum credenda, contra duritiem, et discretum ad refutandum non credenda, contra errorem."

${ }^{28}$ See Summa theologiae, II ${ }^{\mathrm{a}}-\mathrm{II}^{\mathrm{ae}}$, q. 2, a. 3 (ed. Leonina, 28-29).

${ }^{29}$ This is, e.g., the case with heretics, who hold as true some objects of faith that are actually true and others that are not: Thomas Aquinas, Quodlibet VI, q. 4, co. (Opera Omnia 25, vol. 2, ed. Leonina, Rome, 1996, 301): “[...] certitudo inhaesionis non semper provenit ex aliquo habitu; sed ex proprio arbitrio aliquis potest assensum suum firmare ad aliquod verum vel falsum antequam habeat habitum." 
in any way, as it is a mere human judgment. ${ }^{30}$ Thus, it does not enjoy the objective certainty provided by such reliance. In any event, Aquinas never speaks of natural voluntary belief in cases other than religious belief. He does not link this question with other aspects of human existence.

In particular, for Aquinas, the possibility of a natural, firm voluntary assent appears not to have anything to do with rhetoric. Indeed, he calls the assent produced by rhetoric "suspicio," which is defined by the fact that "it does not totally lean towards one part of a contradiction, though it leans more towards one part than towards the other." This contrasts with the opinion produced by dialectic, which totally leans towards one part, though it is still accompanied by the fear that the opposite might be true. ${ }^{31}$ One possible interpretation of this position is that rhetoric produces even weaker adhesion than dialectic.

How then could Aquinas' likely student Giles propose a conception of faith that is based on a comparison with the belief produced by rhetoric? The answer lies in their disagreement regarding the strength of the assent produced by persuasive rhetorical argument. Giles calls this assent fides or credulitas in his commentary on Aristotle's Rhetoric. ${ }^{32}$ Costantino Marmo has already pointed out the differences in vocabulary between Aquinas and Giles: suspicio for the former, fides or credulitas for the latter. ${ }^{33}$ But Giles interpreted his disagreement with Aquinas as not merely of vocabulary, but also as concerning the strength of the adhesion produced by rhetoric. In a transparent reference to Aquinas, Giles says:

\footnotetext{
${ }^{30}$ Thomas Aquinas, Scriptum III, d. 23, q. 3, a. 3, qc. 2, ad 1: "[...] quamvis credant aliquid quod est supra naturam, non tamen credunt illud per habitum infusum quo dirigantur, sed per aestimationem humanam." ${ }^{31}$ Thomas Aquinas, Expositio libri Posteriorum I, lectio 1, n. 6 (Opera Omnia 1*, vol. 2, ed. Leonina, Rome, 1989, 6-7): “[...] quandoque quidem, etsi non fiat scientia, fit tamen fides vel opinio propter probabilitatem propositionum, ex quibus proceditur: quia ratio totaliter declinat in unam partem contradictionis, licet cum formidine alterius, et ad hoc ordinatur topica sive dialectica. Nam syllogismus dialecticus ex probabilibus est, de quo agit Aristoteles in libro topicorum. Quandoque vero, non fit complete fides vel opinio, sed suspicio quaedam, quia non totaliter declinatur ad unam partem contradictionis, licet magis inclinetur in hanc quam in illam. Et ad hoc ordinatur rhetorica."

${ }^{32}$ It must be noted here, by contrast with the text examined at the beginning of the present article, that fides is employed in the stricter sense of credulitas, i.e., the assent produced by rhetoric.

Aegidius Romanus, Expositio super libros Rhetoricorum Aristotilis (Venice, 1515, f. 1rb): "Sunt autem quantum ad praesens tria genera rationum: quia quaedam sunt rationes probabiles, quaedam persuasivae, quaedam demonstrativae. Rationes probabiles sunt dialecticae, persuasivae sunt rhetoricae, demonstrativae vero sunt aliarum scientiarum. [...] per rationes probabiles generatur opinio. Per persuasivas fides aggeneratur, sive credulitas. Per demonstrativas vero efficitur scientia."

${ }^{33}$ C. Marmo, "Suspicio: A Key Word to the Significance of Aristotle's Rhetoric in Thirteenth Century Scholasticism," Cahiers de l'Institut du moyen-âge grec et latin 60 (1990), 145-198, at 187-191.
} 
But some said that credulitas or fides differs from opinion according to certainty, because we adhere more certainly to what we opine than to what we believe (credimus), for credulitas of this kind and above all that which is generated by rhetoric must be called a certain suspicatio. [...] However, these differences are not truly seen or do not reach the root difference. But it is possible that someone adhere more firmly to what he believes than to what he opines. ${ }^{34}$

Giles thus affirms that credulitas can be firmer than opinion. He then proceeds to explain that such credulitas is caused by the will or ordered to the appetite, establishing without ambiguity that he is speaking of the same assent discussed in the first part of this paper, namely assent that is caused by the will and primarily follows a desire rather than reason. ${ }^{35}$ Therefore, it seems that Giles' comparison of faith with rhetoric is made possible by his disagreement with Aquinas.

Having established what conceptual move allowed Giles to defend his theory, I will make a hypothesis on the historical significance of this move, and argue that it can be seen as revealing of the naturalization medieval theories of faith underwent during the thirteenth century.

\section{A Hypothesis on the Historical Significance of Giles' Model}

The example of a biased judgment caused by affections regarding the object of this judgment, which is already mentioned by Aristotle himself in the Rhetoric, ${ }^{36}$ is typical of

\footnotetext{
${ }^{34}$ Aegidius Romanus, Expositio super libros Rhetoricorum Aristotilis (Venice, 1515, f. 1rb): "Dixerunt autem aliqui credulitatem sive fidem differre ab opinione secundum certitudinem, quia certius adhaeremus his quae opinamur quam his quae credimus, nam huiusmodi credulitas et potissime quae generatur per rhetoricam quaedam suspicatio debet dici. [...] Istae autem differentiae vel non videntur vere vel radicalem differentiam non attingunt. Contingit autem aliquem adhaerere firmius his quae credit quam his quae opinatur."

${ }^{35}$ Aegidius Romanus, Expositio super libros Rhetoricorum Aristotilis (Venice, 1515, f. 1rb): “[...] aliquando assentit intellectus secundum motum proprium, aliquando vero ut motum a voluntate; vel aliquando assentit propositionibus quibus secundum se est aptus natus assentire, aliquando vero assentit aliquibus quibus potest fieri assensus ut habet ordinem ad appetitum. Hoc autem si bene advertamus, habemus differentiam inter scibilia, probabilia et persuasibilia. Nam assensus credulitatis per rationes persuasivas competit intellectui secundum quod est aptus natus moveri ab appetitu. Assensus vero scientificus et opinativus sive assentire per propositiones demonstrativas et probabiles competit intellectui ut est aptus natus moveri secundum motum proprium."

${ }^{36}$ See Rhetoric II, c. 1, 1377b-1378a.
} 
both the influence of rhetorical devices and the influence of the will on intellectual assent. To my knowledge, no thirteenth-century doctrine of faith beside Giles' features an explicit comparison between the assent of faith and the assent induced by rhetoric. But there are two such doctrines, one from earlier in the century, Philip the Chancellor's, the other toward the end, Peter John Olivi's, that employ examples of biased judgment that are very similar to Giles'. After succinctly analyzing these examples and explaining how they are used to support different views, I will suggest that this difference highlights the historical significance of Giles' disagreement with Aquinas.

\section{Philip the Chancellor's View}

For Philip the Chancellor, ${ }^{37}$ proper faithful assent seems to depend entirely on God's grace and in no way on the faithful's will. Philip compares the assent given to propositions known by themselves and the assent given to objects of faith. The first kind of propositions, an example of which is the proposition 'a whole is greater than its part', "produce certainty from their own light, which is so manifest that the mind assents [to their truth] willy nilly (velit nolit)." Objects of faith, by contrast, can be the object of doubt.

But if the first truth inspires faith, it rectifies and informs in such a way that, just as one consents willy nilly to this: 'a whole is greater than its part', and this because of its light and evidence, similarly, if one has the habitus of faith, one is willy nilly constrained (artatur) to consent and thus to assent (sentiendum). ${ }^{38}$

\footnotetext{
${ }^{37}$ Here we will be studying passages from question 1 of the Summa de bono's treatise de fide, Philippus Cancellarius, Summa de bono, De fide, q. 1 (ed. N. Wicki, Berne, 1985, vol. 2, 562-579): "Quid sit fides secundum diffinitionem Apostoli."

38 Philippus Cancellarius, Summa de bono, De fide, q. 1 (ed. Wicki, 572-573): "Quedam faciunt certitudinem ex luce sua, que tam manifesta est quod velit nolit assentit mens, ut in universalibus: omne totum est maius sua parte. Sic non est de fide, cum lux eius sit in enigmate, sed hanc virtutem potius habet ex informatione conscientie. Quod patet; de hac enim: omne totum est maius sua parte numquam potuit dubitare, sed quam cito auditur creditur et intelligitur. Sed antequam illuminetur quid a Deo per fidem de articulo ut est: Filium Dei incarnatum esse, dubitare potest et potest ei persuaderi per exempla vel rationes, licet non ita evidenter. Sed si prima veritas fidem inspiraverit, ita rectificat et informat quod, sicut quis velit nolit consentit huic: omne totum est maius sua parte, et hoc propter suam lucem et evidentiam, ita velit nolit, si habet fidei habitum, artatur ad consentiendum et ita sentiendum. Et quod habet istud per lucem, habet istud per conscientie informationem, quia ita informata est conscientia et ita artatur quod contra se ipsam iam negaret, cum ita sentiat, et de adulto loquor."
} 
So, whether one wants it or not (velit nolit), i.e., without any operation of the will, when one has supernatural faith, one assents to the truth of the objects of faith. Philip contrasts this with how affection can move someone to naturally believe something firmly:

[W]hile in other matters knowledge is the principle of affection or of love, the principle of this knowledge [of faith] is affection or love. And it is just as it happens with ordinary love. Someone often cares for someone else with so much love that this ardor does not allow her to believe or suspect anything sinister about the other. Similarly, the affection one has for God, by which she believes Him about everything, does not put up with anything, whether it is in sense or reason, that seems to be incompatible with the faith. And if one objects that a heretic exposes herself to death for her error, this poses no difficulty, because it is rather favorable to faith. Indeed, the heretic dares to do this only because she holds her error as faith. Therefore, this must be compared to faith. From this, one can judge how virtuous the truth of the faith is, since an image can [be the basis through which that of which it is an image may be judged], just as the virtue of the true good can be judged in an apparent good. ${ }^{39}$

It seems then that, even though, for Philip, the supernatural habitus of faith is enough to cause firm belief in the objects of faith, one also has the power, by one's own will and without divine help, as the case of the heretic makes clear, to firmly believe what one wants because of one's own natural affection.

Philip therefore seems to defend a doxastic voluntarism that is very similar to Giles' on the basis of the same social and psychological reality: one's affection can make one believe something firmly and naturally without consideration of the evidence. The main difference between them is that, while Giles uses this example as an illustration of how

\footnotetext{
39 Philippus Cancellarius, Summa de bono, De fide, q. 1 (ed. Wicki, 576): “[...] cum in aliis cognitio sit principium affectionis sive amoris, cognitionis huius est principium affectio sive amor. Et est sicut contingit in amore vulgari quod plerumque tanto amore aliquis zelat alium, quod ipse zelus non permittit ipsum credere vel suspicari de illo aliquid sinistrum, ita affectio quam habet quis ad Deum, per quam in omnibus ei credit, non sustinet aliquid sive in sensu sive in ratione quod videatur fidei repugnare. Nec obstat si quis obiciat de heretico qui se exponit morti pro errore suo, quia potius in hoc commendatur fides; non enim audet hoc nisi quia errorem habet pro fide, unde hoc ipsum est in comparatione ad fidem. Unde perpendi potest quante sit virtutis veritas fidei, cum hoc possit ymago, sicut in apparenti bono perpenditur quanta sit virtus veri boni."
} 
proper, virtuous faith works to produce assent, Philip contrasts the wholly supernatural and involuntary way in which virtuous faithful assent is produced with the way in which natural faithful assent can occur in a heretic because of her affections.

This does not mean that affections play no role in the virtuous faithful: indeed, it seems that they make them refuse anything that contradicts the objects of faith. Moreover, the virtuous faithful have an affection for God "by which they believe Him about everything." This probably means that they approve their own beliefs because they follow from an illumination from the God they love. This may even mean that, if they did not have supernatural faith, they would nonetheless believe by their own will because of this affection. But it is clear nonetheless that this affection does not produce virtuous faithful assent, since supernatural faith explicitly leaves no choice but to believe in the objects of faith once they are apprehended, for those who have it.

Not taking ordinary natural belief to work in the same way as supernatural belief is common in the early thirteenth century. For Alexander of Hales (ca. 1185-1245), the first great Franciscan scholastic, natural, acquired faith is a "credulitas, persuaded [to the believer] through argument, experience, or teaching." 40 Such a naturally acquired habitus could never be a proper habitus of faith, because a supernatural habitus that elevates the intellect beyond itself is required for it to assent to objects which exceed the intellect's capacity for apprehension. ${ }^{41}$ In fact, acquired faith, such as that which can be drawn from the authority of the Church Fathers, amounts to nothing more than opinion, meaning that it does not have the required firmness to be considered a kind of faith. ${ }^{42}$ Thus, the distinction in Giles between opinion and credulitas highlighted above is entirely absent

\footnotetext{
${ }^{40}$ Alexander Halensis (attributa), Summa theologica, (vol. 2, ed. Quaracchi, 1928, 1033): "Nam fides, quae erat acquisita ex rationibus seu ex coniecturis miraculorum et prophetiarum, non est fides informis, secundum quod hic loquimur. Unde notandum quod fides informis potest dici duobus modis: privative et negative. Negative potest dici fides informis qualitas seu credulitas persuasa ratione vel experimento vel doctrina. Privative vero dicitur qualitas, quae quidem privatur forma virtutis, quam nata est habere, quemadmodum dicitur informis fides, qua assentitur primae Veritati propter se, quamvis careat amore super omnia."

${ }^{41}$ Alexander Halensis, Summa theologica, (ed. cit., 1032): "[...] per fidem informem elevatur intellectus supra se; sed per nullum habitum naturalem vel acquisitum potest intellectus elevari supra se; ergo fides informis non est habitus naturalis vel acquisitus; ergo est habitus gratuitus, cum constet quod per fidem informem elevetur intellectus ad credulitatem divinae humanationis et distinctionem divinae Trinitatis, quae, constat, excedunt apprehensionem humani intellectus per naturam."

${ }^{42}$ Alexander Halensis, Glossa in quatuor libros Sententiarum Petri Lombardi, 1. III, d. XXIII (L) (vol. 3, ed. Quaracchi-Florence, 1954, 280): 'Magister sic: 'Antiqui Patres crediderunt ita: ergo hoc est verum'. Sed hic est locus logicus ab auctoritate, qui non facit nisi opinionem; fides autem est supra omnem opinionem et scientiam."
} 
here, since Alexander uses the latter term to designate the opinion that acquired faith is. It can be assumed that, for Alexander, a belief that is neither opinion nor science requires supernatural support to exist.

As for Bonaventure (ca. 1217-1274), also a Franciscan and one of the most important theologians of the thirteenth century, he defends a doctrine of faith that is very similar to Alexander's. According to him, natural voluntary belief, motivated by "love and reverence for the speaker," is possible, but lacks the strength necessary to produce a proper faithful assent. ${ }^{43}$ One might surmise that it does not produce the necessary certainty of adhesion and thus that it is even less comparable to proper faith than it is in Philip's view.

We have already shown that Aquinas, though he seems to accept firm voluntary natural belief akin to Philip's, does not take it as a model of how virtuous faith works either, and he certainly does not link it to the question of affective bias, seeming rather to think that, if such bias is to be likened to the effect of rhetorical devices, it can produce nothing more than a suspicio, as we have seen.

\section{Peter John Olivi's view}

For Olivi, at the end of the thirteenth century, things are different. ${ }^{44}$ When discussing faith, he first aims to show that love can lead to belief by means of an example very similar to Giles': “[W]e see that many men believe and presume bad things of an enemy more willingly than of a friend, and good things more willingly and easily of a friend than of an enemy, even though they have more reasons to believe the opposite. ${ }^{45}$ It is as though Olivi reprised Giles' example and highlighted the power of love even more. As

\footnotetext{
${ }^{43}$ Bonaventura, Commentaria III, d. 23, a. 2, q. 2, resp. (ed. cit., 481): "Nam quidam assentiunt veritati auditae moti humana persuasione, utpote propter amorem et reverentiam dicentis vel propter miracula vel propter rationes et argumenta; et talis fides est simpliciter acquisita nec dicenda est habere rationem virtutis, quia nullius est vigoris nec roboris, sublata de medio ipsa humana ratione."

${ }^{44}$ Here we will be studying passages from Olivi's quaestiones de fide, which are, among his quaestiones de virtutibus, qq. 8: "Quaeritur an sit possibile ac debitum et virtuosum credere sine ratione," and 9: "Iuxta hoc quaeritur an fides primo et principaliter innitatur alicui obiecto et per illud aliis, vel omnibus aequaliter et uniformiter"; as well as from q. 3 from his quaestiones de Deo cognoscendi: "Tertio quaeritur an Deum esse sit per se notum aut per rationes necessarias demonstrabile an sola fide creditum." According to Sylvain Piron's as yet unpublished estimation, it was written in the 1290s. I thank him for his help.

${ }^{45}$ Petrus Iohannis Olivi, Quaestiones de incarnatione et redemptione, quaestiones de virtutibus, q. VIII, resp. I, 1 (ed. Emmen et Stadter, 321): “[...] constat quod potest amore affici nunc ad hoc, nunc ad oppositum, et libentius consentire in unum eorum credendum quam in reliquum. Unde et videmus multos libentius credere et praesumere mala de inimico quam de amico, et bona libentius et facilius de amico quam de inimico, quamquam plures rationes habeant pro parte contraria quam pro sua."
} 
we have seen above, Giles imagined we had the same argument in favor of the friend and the enemy and that the will influenced how it was received in such a way that it produced belief as regards the friend and not as regards the enemy. Olivi takes it one step further: there are more arguments in favor of the enemy (just as the arguments against faith were deemed by Giles more efficient than the arguments for it) but still the will makes one decide in favor of one's friend.

Olivi describes the influence of the will as something akin to directing the intellect's attention: ${ }^{46}$ the more the intellect is "moved and applied" by the will to what we want to think of, "the stronger the bond by which it is rooted and united to its object" and "the more firmly and intensely it assents to it." ${ }^{\prime 47}$ The certainty of the belief that results from this process is the same as what we have regarding the truth of a thing we have before our own eyes. It is in this way that the catholic faithful, as well as heretics, want to believe and do believe "in an absolutely and wholly immobile way." 48

How then to differentiate catholic firm belief from other, heretical beliefs? Olivi describes a unique process by which catholic believers can come to true virtuous belief (as opposed to belief produced by social processes or affections for community figures, and especially parents, which holds neither moral nor epistemic value ${ }^{49}$ ). Just as for Giles,

\footnotetext{
${ }^{46}$ Faucher, Les garanties de la foi, 76-79.

${ }^{47}$ Petrus Iohannis Olivi, Quaestiones de incarnatione et redemptione, quaestiones de virtutibus, q. VIII, resp. I, 2 (ed. Emmen et Stadter, 321): “[...] intellectus movetur et applicatur a voluntate ad illa quae volumus cogitare, et secundum hoc quod magis volumus vel nolumus, majus et minus applicatur vel retrahitur. Constat autem quod quanto fortius applicatur, tanto ceteris paribus fortiori nexu invisceratur et unitur suo objecto, ac per consequens et tanto firmius et intensius assentit."

${ }^{48}$ Petrus Iohannis Olivi, Quaestiones de incarnatione et redemptione, quaestiones de virtutibus, q. VIII, resp. I, 4 (ed. Emmen et Stadter, 322): "Tertio modo est idem quod firmiter tenere rem pro vera et ei adhaerere firmiter tamquam si coram se praesentialiter eam cerneret et haberet. Et hoc modo assentimus illis quae absolute et omnino immobiliter volumus credere et tenere. Et hoc modo fideles credunt dogmata fidei catholicae et haeretici dogmata suarum haeresum et sectarum." See also (329): “[...] certitudo fidei duo aut tria in se includit. Primum est realis et infallibilis veritas creditorum. - Secundum est firma et inconcussibilis adhaesio ad veritatem creditam, repellens a credente omnem dubietatem aut saltem ejus aequiparantiam respectu sensus veritatis creditae et fixae adhaesionis ad ipsam. Duo autem ultima possunt dari a voluntate tamquam a causa motiva, quamvis actus illi immediate eliciantur ab intellectu. Non tamen possunt sibi quomodocumque dari, immo oportet objectum prius sub modo debito sibi proponi et ipsammet voluntatem ad sic movendum intellectum divinitus affici et erigi ac vigorari. - Si tamen nomine certitudinis intelligatur quaecumque aestimatio, quam quis vere vel falso aestimat esse certam, sic de omni eo, [circa] quod per imperium voluntatis nostrae possumus fortem credulitatem habere, possumus eo ipso talem certitudinem concipere."

${ }^{49}$ Petrus Iohannis Olivi, Quaestiones de incarnatione et redemptione, quaestiones de virtutibus, q. IX, sol. 8 (ed. Emmen et Stadter, 355): “[...] licet consuetudo seu assuefactio seu continua experientia fidei parentum et domesticorum aut concivium suorum habeat vim vehementer inductivam ad fidem veram vel erroneam, [nihilominus si] huic consuetudini principaliter innitantur, non aliter divinitus moti, nisi sola affectione humana et sola aestimatione credulitatis parentum et concivium suorum, absque divina
} 
it is for Olivi based on love for God. ${ }^{50}$ There is a "most natural instinct" that causes men, upon merely thinking of the concept of the supreme being that is God, to be taken with admiration and love for Him as well as with the feeling that He could exist and must be worshipped.

Such a love for God precedes, for Olivi, the belief that He exists. It is in fact the motive for such a belief, without which no one could properly worship God. Similarly, believing the different truths of faith allows the faithful to better believe in God, and this is the motive for the faithful's voluntary belief in them. That does not prevent Olivi from saying that God testifies for the truths of faith and is reflected in them. ${ }^{51}$ For Olivi, faith is directed towards God and what is to be believed about Him in the way vision is directed by a reflection towards the thing that is reflected. ${ }^{52}$ The best interpretation we can give of this doctrine is that, for Olivi, God is directly, evidently perceptible to us as good, though not as true or real, through the mere concept of Him and through all truths of faith inasmuch as they allow us to better understand and respond to this goodness. Indeed the "general objective reason of faith," i.e., the way in which a truth of faith is presented as such to us, is either "a truth divinely proposed in order to believe in God and worship Him, or a truth necessary in order to duly believe in God and worship Him, or a believable truth leading perfectly towards God." ${ }^{.53}$ The fact that God's goodness is perceived in such

aestimatione veritatis divinae a parentibus creditae et sibi per eos propositae, non habent fidem catholicam et virtuosam et divini cultus fundativam."

${ }^{50}$ Petrus Iohannis Olivi, Quaestiones in secundum librum Sententiarum, De deo cognoscendo, q. III (vol. 3, ed. B. Jansen, Quaracchi, 1926, 544): "[...] cum [mens] audit vel per se concipit altitudinem summi entis summamque ejus justitiam et potestatem et bonitatem, quodam naturali instinctu timore tam reverentiae quam poenae concutitur et in ipsius cogitatu et auditu admirationis stupore repletur et quodam naturali amore ejus afficitur. Statim enim quodam naturalissimo instinctu ex sensu inferioritatis sentit se posse habere superius quem timere et revereri debeat, immo, acsi ipsum sentiret, mens cogitatu vel auditu sic afficitur, quantum est de se vi naturalis instinctus."

${ }^{51}$ Petrus Iohannis Olivi, Quaestiones de incarnatione et redemptione, quaestiones de virtutibus, q. IX, sol. 6 (ed. Emmen et Stadter, 354): "Quando autem dicimus quod nos credimus Deo propter se et cetera propter ipsum, non est sensus quod illa credamus propter hoc quod ipse sit, sed potius quod propter hoc credimus illa, ut perfectius Deum credamus et ut perfectius Deo per fidem adhaereamus. Vel sensus est quod credimus illa propter Deum testificantem illa et in illis quodammodo relucentem."

52 Petrus Iohannis Olivi, Quaestiones de incarnatione et redemptione, quaestiones de virtutibus, q. IX, sol. 7 (ed. Emmen et Stadter, 355): “[...] est ferri ad aliquid ut alterius rei signum vel speculum et est ferri ad aliquid ut ad terminale objectum. Primo modo fertur intellectus scientis vel credentis super species memoriales et super compositionem seu coordinationem earum. - Secundo modo fertur super res quas illis mediantibus aspicit; et hoc secundo modo fertur fides in Deum aut in sua credita. Hoc etiam modo prius fertur in divinum esse sive absolute sive relate ad alia sumptum quam ad illa alia."

${ }^{53}$ Petrus Iohannis Olivi, Quaestiones de incarnatione et redemptione, quaestiones de virtutibus, q. IX, resp. 3 (ed. Emmen et Stadter, 345): “[...] generalis ratio objectiva fidei [...] est aut veritas divinitus proposita ad credendum et colendum Deum, aut veritas necessaria ad debite credendum et colendum Deum, aut veritas credibilis perfecte in Deum ducens." 
truths thus constitutes His testimony in their favor. It is through this process that God, after showing His goodness to us and making us love Him, shows us why the objects of faith should be believed out of this love. In line with Giles' view, it can be said that it puts God in the position of a rhetor. At the same time it does not threaten the status of faith as obscure knowledge, inasmuch as it does not give us direct epistemic access to the truth of God's existence and attributes, or of any other object of faith. It is a remarkable attempt at accounting for the Apostle Paul's famous words, referring to the present faithful knowledge of the viator as being a vision "through a glass, darkly." 54

It is clear that Olivi proposes an original and subtle doctrine that, using the same elements Giles of Rome put forward in his account of faith, allows him to build a coherent view of faith that never relies on supernatural processes and explains mundane voluntary beliefs as much as religious voluntary beliefs using the same devices, just as Giles seemed to do. As far as I know, such a naturalistic model of voluntary belief is unprecedented among previous medieval thinkers. ${ }^{55}$

Whether or not Giles of Rome had any direct influence on Olivi is not of present consern. I merely note that (1) before Giles of Rome, it seems that no medieval thinker thought of ordinary voluntary belief produced by affective bias as relying on psychological processes similar to those virtuous faith relies on. Philip the Chancellor's doctrine remarkably illustrates this point in how differently he makes use of an example of affective bias similar to Giles'. We also note that (2) after Giles defended his doctrine (at the beginning of the $1270 \mathrm{~s}^{56}$ ), at least one author, Peter John Olivi, described virtuous faithful belief as relying on the same psychological processes as affective bias, like that produced by rhetoric, using, again, an example of such bias very similar to Giles'. Duns Scotus, after Olivi, would go on to defend a view of virtuous faith that is not likened to affective bias or the assent induced by rhetoric but that nonetheless describes virtuous faithful assent as relying on psychological processes identical to those ordinary firm and voluntary belief rely on.

Independently of any real historical influence Giles may have had on Olivi and later thinkers on the question of faith, which remains to be established, I thus contend, nonetheless, that the conceptual shift from Aquinas' view that makes Giles' view possible

\footnotetext{
${ }^{54}$ I Cor. 13:12.

${ }^{55}$ Faucher, Les garanties de la foi, 291-304.

56 See Lambertini, "Giles of Rome."
} 
appeared at a pivotal moment in the development of thirteenth-century theories of faith and is a striking illustration of the process of naturalization they underwent during the century.

\section{Conclusion}

In this paper I have endeavored to show that, in his Rhetoric commentary, Giles likens the voluntary assent of faith to the voluntary assent produced by rhetoric, in explicit opposition to Aquinas' own view. This shift allows Giles to propose a comparison with virtuous faith and leads him to identify the affection that humans feel towards God as the main motivation and cause of virtuous faithful belief, just as an affective bias produced by rhetorical devices can lead one to naturally and firmly believe something independently of the weight of the evidence. I conjecture that this move is representative of the process of naturalization thirteenth-century theories of faith underwent, as is shown by how differently Philip the Chancellor, at the beginning of the century, and Peter John Olivi, toward the end, use examples of affective bias very similar to Giles'.

Comparing faith with the assent produced by rhetoric provokes specific questions. For instance, one of the main properties of the act of faith is that it is free; otherwise, it could not be said to be virtuous, nor could faith be said to be a virtue. But when we think of rhetorical discourse, we usually think that the active power is the speaker while the audience is merely a passive power: the simple act of listening to a good rhetor is supposed to lead to the production of specific representations that in turn produce the belief the speaker aimed to produce. If faith is supposed to rely on the same kind of mechanism, does that not imply that faithful assent is not free? Should we rethink our views on the power of rhetoric and seriously consider the possibility that the members of an audience are always free to give their assent? Could this problem be linked to the fact that the will, for medieval authors, is the faculty of volition and of emotion or passion, and thus seems to be by definition, on the one hand, entirely free and, on the other, entirely determined in different functions? Such questions can perhaps be answered through the systematic study of the psychological underpinnings of medieval rhetorical theories, which to our knowledge has yet to be undertaken. 